\title{
Congress of Orientalists
}

THE 23 rd International Congress of Orientalists was held at Cambridge from 2 I-27 August I954, and, for the first time, included among its groups a section on Africa. Led by Professor M. Guthrie of the School of Oriental and African Studies, London, the section was attended by some two dozen members, including delegates from France, Holland, Belgium, Germany, and the Soviet Union.

The establishment of the section on a geographical basis meant that some divergence of interest was apparent: while many of the papers were specifically linguistic, a number of delegates offered contributions of an anthropological or more general nature, so that the technical terms of one discipline may have been unfamiliar to members of another. Some disadvantages arose from the practice whereby papers followed one another virtually without a break, and discussion provoked by the many stimulating contributions had necessarily to be strictly limited, even though opportunities for further discussion were available during the afternoons and evenings.

Some idea of the range and specialization involved may be gained from the following titles: 'Is Somali a Tone Language?' (B. W. Andrzejewski), a technical paper on the tonal features of the language and problems of classification; 'Dravidian Elements in Egypt and Africa' (L. Homburger), a more general consideration of the affinities of Dravidian elements with those in Egyptian and African languages; "The Social and Economic system of the S. Bantu at the beginning of the Igth century" (I. Potekhin); "The specific contents of Swahili culture viewed against the background of the culture area concept ' (A. H. J. Prins), an introduction to Swahili culture; 'Word-tone and Sentence intonation in the BrassNimbi dialect of Ijaw' (E. C. Rowlands), a specialist linguistic study; 'Eine bisher nicht beachtete Nominalklasse des Ful' (H. A. Klingenheben); 'The Classification of African Languages' (J. Berry).

In all, some fifteen papers were presented, giving a valuable conspectus of research being undertaken in the African field. Communicated by Wilfred Whiteley.

\section{Séminaire semestriel des Sciences humaines de l'I.R.S.A.C.}

Pour la quatrième fois les spécialistes en sciences humaines de l'Institut pour la Recherche Scientifique en Afrique Centrale se réunirent au Centre d'Astrida de l'Institut du 28 juin au 4 juillet. Prirent part à cette semaine de travaux: MM. J. J. Maquet, Chef du Centre, D. Biebuyck, J. Vansina, L. de Heusch, ethnologues; J. Hiernaux, anthropologue physique; A. Coupez et J. Jacobs, linguistes; C. Dereine, bibliothécaire de l'Institut; R. de Wilde et R. Thys, assistants de recherche.

Chaque participant donna un rapport sur l'état d'avancement des recherches poursuivies sur le terrain et exposa son plan de travail pour le second semestre 1954 .

Les communications suivantes furent présentées et discutées: Structure politique des Kuba (Vansina); Parenté morphologique des populations du Kivu et du Ruanda-Urundi, État actuel des connaissances sur la préhistoire du Ruanda-Urundi (Hiernaux); Composition et migrations des groupes Bazyoba, Babembe et Balega, Quelques aspects de la structure du bwamé chez les Balega (Biebuyck); Mot étranger et onomatopée monosyllabique en tetela, Radical verbal en tetela et son aspect dialectologique, Langue tambourine et anthroponymie (Jacobs); Sociologie du deuil (de Heusch); Existence de y et w comme phonèmes autonomes en rwanda, Résultats provisoires de l'application de la lexicostatistique de M. Swadesh à des langues du Congo Belge (Coupez); Techniques d'enregistrement et de conservation du son (Thys). Communicated by Jacques $J$. Maquet.

\section{Rhodes-Livingstone Institute}

THE eighth conference of research officers was held at Lusaka from I4 June to 19 June I954. 